thy Haitian immigrants. $N$ Engl $J$ Med 1983;308: 125-9.

${ }^{8}$ Luft BJ, Conley F, Remington JS, et al. Outbreak of central nervous system toxoplasmosis in Western Europe and North America. Lancet 1983;i:781-3.

- Szychowska Z, Prandota-Schoepp A, Chabudzinska S. Rifampicin for pneumocystis carinii pneumonia. Lancet 1983; i: 935.

${ }^{10}$ Hughes WT, McNabb PC, Makres TD, Feldman S. Efficiency of trimethoprim and sulfamethoxazole in the prevention and treatment of pneumocystis carinii pneumonitis. Antimicrob Agents Chemother 1974;5:289-93.

"Oleske JM. Effects of antimicrobials on host defence mechanism. J Antimicrob Chemother 1984;13:413-5.

\section{Alcohol induced liver disease}

Dr Fleming's and Professor McGee's excellent review of alcohol induced liver disease $^{1}$ contained the following sentence: "The hepatocyte may be massively swollen, often being three times normal size." This could mean that the cell volume is three times normal, the cross sectional area is three times normal (therefore cell volume roughly five times normal), or the cell diameter is three times normal (therefore cell volume roughly 27 times normal). In this instance the photographs imply that the cell diameter is three times normal, but this inaccurate usage of the undefined term size is widespread throughout medical published work and may lead to serious misunderstandings.

\section{Bronglais General Hospital, Aberystwyth SY23 1ER}

\section{Reference \\ ${ }^{\prime}$ Fleming KA, McGee JO'D. Alcohol induced liver disease. J Clin Pathol 1984;37:721-33.}

Professor McGee replies as follows:

Dr Simpson makes a very cogent point in that the term size is open to misinterpretation when applied to a histological feature in a tissue section. When we stated that "The hepatocyte may be massively swollen, often being three times normal size" we did, in fact, mean that the maximum dimension of the two dimensional image of a hepatocyte was three times normal. We did not imply that size referred to diameter. Only circles have diameters; swollen hepatocytes are not circles and cannot be defined accurately by any standard geometric shape.

JO' D McGEE

Nuffield Department of Pathology, John Radcliffe Hospital, Headington, Oxford $O X 39 D U$
Value of factor VIII related antigen as a means of demonstrating extramedullary megakaryopoiesis

We were interested to read the brief report by Dr Crocker and Dr Smith on the value of factor VIII related antigen (VIIIRAg) as a marker for the immunohistological demonstration of megakaryocytes.' Since the original immunological localisation of VIIIRAg in platelets ${ }^{2}$ this antigen has been used as a marker for these and for megakaryocytes, ${ }^{3}$ but a word of warning is needed. Most commercial antisera of the type recommended by Dr Crocker and Dr Smith are prepared for relatively insensitive immunoprecipitation assays of VII-IRAg (von Willebrand factor antigen) and are not necessarily sufficiently specific or purposely absorbed for the much more sensitive immunohistological methods. ${ }^{4}$ Thus antisera may be contaminated with weak antibodies to fibronectin or other antigens and much more rigorous testing is needed to ensure monospecific antisera for immunohistological work. ${ }^{4}$ Use of monoclonal antibodies to VIIIRAg or antisera to specific platelet antigens such as $\beta$ thromboglobulin could circumvent these problems. Blocking controls using commercial "factor VIII" are not answers to this problem since even high potency therapeutic concentrates are crude mixtures of factor VIII complex (factor VIII coagulant and von Willebrand factor) with fibronectin, fibrinogen, and other proteins which, in fact, are their main constituents. In addition the difference between "factor VIII related antigen" and "factor VIII" is an important semantic problem which should be recognised by histologists. ${ }^{\circ}$

AL BLOOM
JC GIDDINGS
Department of Haematology,
University of Wales College of Medicine,
Heath Park,
Cardiff

\section{References}

' Crocker J, Smith PJ. Value of factor VIII related antigen as a means of demonstrating extramedullary megakaryopoiesis. $\mathrm{J}$ Clin Pathol 1984;37:834-5.

2 Bloom AL, Giddings JC, Wilks CJ. Factor VIII on the vascular intima: possible importance in haemostasis and thrombosis. Nature New Biology 1973;241:217-9.

${ }^{3}$ Innes DJ Jr, Mills SE, Walker GK Megakaryocyte leukaemia: identification utilising anti-factor VIII immunoperoxidase. Am J Clin Pathol 1982;77:107-10.
4 Giddings JC, Jarvis AL, Bloom AL. Differential localisation of porcine factor VIII related antigen (VIIIRAg) in vascular endothelium and endothelial cells in culture. Thromb Res 1983;29:299-312.

${ }^{5}$ Giddings JC. The purification of factor VIII and IX and production of specific antisera. In: Bloom AL, ed. The hemophilias. Edinburgh: Churchill Livingstone, 1982:51-82.

- Bloom AL. The mysteries of the factor VIII molecule. In: Woolf $\mathrm{N}$, ed. Biology and pathology of the vessel wall. Eastbourne: Praeger, 1983:129-46.

\section{Book Reviews}

Aluminium Analysis In Biological Fluids. Ed MR Wills and J Savory. (Pp 132; $\$ 25.00$.) University of Virginia Press, USA. 1983.

These are the proceedings of a conference held at the University of Virginia in June 1983. To some, aluminium analysis might seem to be a rather esoteric topic for a meeting and the proceedings likely to be of little interest to pathologists. But even though the clinical importance of aluminium has been recognised for barely ten years the measurement of aluminium in water supplies, biological fluids, and tissues has become an important procedure in many clinical laboratories. Thus the clinical and toxicological importance of aluminium is now well established and should be of general interest to all pathologists.

Aluminium is the third most abundant element in the earth's crust and it is widely distributed in nature. In the healthy adult, the body-burden of aluminium is less than $300 \mathrm{mg}$. However, in patients with chronic renal failure there is unequivocal evidence of a general increase in the body burden of aluminium. In such patients aluminium is strongly implicated in the aetiology of encephalopathy, microcytic anaemia, and osteomalacia. It may be implicated also in the pathogenesis of Alzheimer's disease and some other neurological disorders, although here the evidence is less certain.

In their foreword to the conference proceedings the editors state that their purpose was to review the "state of the art" in analytical methods for the assay of aluminium in biological material. In this reviewer's opinion they have succeeded admirably in the task. The volume contains 14 papers on various aspects of analysis from acknowledged experts in the field. The variety of techniques reviewed includes electrothermal (flameless) atomic absorption spectrophotometry, neutron activation analysis, scanning electron mic- 
roscopy, X ray spectrometry, and other microprobe techniques. Clearly, many of these techniques are only available in specialised centres but atomic absorption spectrophotometry is used in many service laboratories. In fact the analysis of aluminium in biological material is far from simple, especially in respect of sample preparation and the prevention of contamination. All of these aspects are well covered in the various reviews together with important consideration on the quality assurance of aluminium analyses and interlaboratory comparisons. In addition, there are interesting contributions on the analysis of aluminium in other materials such as hair, the speciation of aluminium in plasma, and its interaction with macromolecules.

These proceedings offer a valuable source of interesting and useful information to chemical pathologists, haematologists, and histopathologists concerned with the clinical problems arising from aluminium toxicity. The volume should be essential reading for any laboratory intending to commence work on the measurement of aluminium. This is a timely and inexpensive review of an important problem: highly recommended.

RA BRAITHWAITE

Colour Atlas of Neuropathology. RO Weller. (Pp 207; 440 illustrations in colour; £42.) Oxford University Press. 1984.

There have been a number of neuropathology textbooks published recently written mainly for general pathologists. This is the latest and by far the best, combining brain, peripheral nerve, and muscle histology in the same volume. Professor Weller has managed to find good examples of some rather rare conditions as well as the standard material. He has shown the value and the necessity of special techniques, including resin sections and some immunocytochemistry in neurological diagnosis.

The muscle section in particular is well illustrated and shows that without these techniques muscle biopsy is of limited value. In the peripheral nerve section he illustrates the importance of resin sections but not the use of osmium, which is easier for most departments than the methods he does show, and there are no teased preparations of segmental demyelination.

The brain section, although slightly shorter than other texts in this field, does contain all the general pathologists needs to know, and the juxtaposition of smears and sections of brain tumours is helpful.
The colour of the pictures is of high quality throughout and, although it is expensive, the pathologist is getting information which would normally need three textbooks.

BARBARA SMITH

History of Clinical Cytology. A Selection of Documents. 2nd ed. H Grunze and AI Spriggs. (Pp 206; US\$45.00.) G-I-T Verlag Ernst Giebeler. 1983.

This is a most enjoyable book. A brief account of the original scientific observations is followed by the story of those early workers who applied their observations to clinical conditions. Most of the book, however, is devoted to developments in clinical cytology in the past 150 years. One is impressed by the diversity of character and professional background of those who made major contributions. The authors have succeeded in capturing their enthusiasm and passionate attention to detail, and the book is elegantly illustrated in the many reproductions of early illustrations. While this is not in any sense a textbook, it demonstrates repeatedly the importance of accurate observation, the value of the correlation of clinical, cytological, and histopathological findings, and the need for critical review of diagnoses. For these reasons and, especially, perhaps because it encourages anyone entering the field to share the authors' lifelong enthusiasm for their subject, the book can be recommended to the library of any department practising diagnostic clinical cytology.

HELENA E HUGHES

Muscle Pathology. Contemporary Issues in Surgical Pathology. Vol 3. Ed Reid R Heffner. (Pp 235; £33.) Churchill Livingstone. 1984.

The stated intention of the fourteen authors of "Muscle Pathology" was to write a book for practising pathologists and in many respects they have succeeded in this aim. Most texts on muscle disease are clinically orientated and cover mainly the neurological aspects of the disease; this book, on the other hand, gives a broad view of muscle pathology. There are two succinct and well-written chapters on focal inflammatory disease of muscle and neoplasms of skeletal muscle; these aspects are usually omitted from other books on muscle pathology. The early chapters deal briefly with the clinical aspects of muscle disease and the techniques of histological and histochemical preparation. There is a useful chapter on morphometric analysis of biopsies and a helpful section on the genes eral pathology of muscle. Some authors express an individualistic but stimulating. approach to muscle pathology, especially it the chapter on core-genic myopathies? Overall, this recent edition to the contem음 porary issues in Surgical Pathology offers new approach to muscle disease, and thiş volume will be a useful introduction an reference text to most histopathologists. 을 RO WELLER

Cardiac Pathology. An Integrated Text and Colour Atlas. Anton E Becker and Robert H Anderson. (£48.) Churchill Livingstone 1984.

The book is divided into two sections. $\omega$ first consists of 16 chapters and concisely describes acquired disorders of the catdiovascular system. It also includes ât excellent chapter on the related changes seen within the lungs and illustrates weff the histological features in pulmonary hypertension.

The second part is devoted to congenitaf heart disease. This is covered in greate detail than is usual in an atlas and, studied, a considerable understanding ca be gained of an often confusing subject The author's approach is logical and b\&egే on simple anatomical concepts and $\bar{T}_{\mathrm{T}}^{\circ}$ terminology used is defined within the tial chapters devoted to this subject.

The text is liberally illustrated and the quality of the photographs is outstanding both of gross and microscopic specimen\& Throughout the text simple line drawings are used to complement the photographs and this makes a very effective teaching method. The range of specimens illustrate is excellent, based on the combined exper? ence of the two authors.

This book will be of great value to sture dents of pathology at all stages of thei career. Those beginning will find it a usefit introduction on the physical signs to look. for when examining a heart; those taking examinations will find it useful as an easil digested review.

The book is good value for money and $\mathrm{i}$ 용 strongly recommended for purchase by the departmental library.

SARAH HILÑ

Perinatal Pathology. Major Problems Pathology Series. Vol 15. JS Wiggleswort (Pp 480; £42.50.) WB Saunders Companyu 1984.

In this book the author sets out to provic practical information on a difficult subjeç 